\title{
ANÁLISE DA EROSÃO LAMINAR EM ÁREAS COM USO AGRÍCOLA E PASTAGEM: BACIA HIDROGRÁFICA DO RIO TENENTE AMARAL - MT
}

Cleberson Ribeiro de Jesuz ${ }^{1}$ Ivaniza de Lourdes Lazzarotto Cabral²

Resumo: O sistema hidrográfico do rio Tenente Amaral tem a sua área inserida nas unidades morfoesculturais da Depressão Interplanáltica de Rondonópolis e do Planalto e Chapada dos Guimarães. O trabalho apresenta os resultados do monitoramento de deslocamento de material por erosão superficial em dois experimentos situados em área de pastagem e agricultura durante o período de setembro de 2013 a agosto de 2014 na morfoescultura de Planalto. No período a área com agricultura apresentou um acumulado de $7.026 \mathrm{~mm}$ de precipitação, e taxa de material erodido de $347,8 \mathrm{~g} / \mathrm{l}$, totalizando $24,18 \mathrm{~kg} / \mathrm{m}^{2} / \mathrm{ano}$. Enquanto, a pastagem teve volumes de $6.667 \mathrm{~mm}$, taxa de material erodido de 215,8 $\mathrm{g} / \mathrm{l}$, e total de material erodido de $25,91 \mathrm{~kg} / \mathrm{m}^{2} / \mathrm{ano}$. Em ambas as áreas o tipo de material deslocado está representado pela areia em primeiro lugar, seguida pela argila e, em menor volume, 0 silte.

Palavras-chave: Erosão laminar. Rio Tenente Amaral. Calhas de Gerlach.

\section{ANALYSIS OF LAMINAR EROSION IN AREAS WITH AGRICULTURAL AND PASTURE USAGE: HYDROGRAPHIC BASIN OF THE TENENTE AMARAL RIVER - MT}

Abstract: The hydrographic system of the Tenente Amaral river has its area inserted in the morphosculptural units of the Interplateau Depression of Rondonópolis and the Plateau and Chapada dos Guimarães. The work presents the results of the monitoring of displacement of material by surperficial erosion in two experiments located in pasture and agriculture areas during the period from September 2013 to August 2014 in the morphosculpture of the Plateau. In the period, the area with agriculture presented a cumulative of $7,026 \mathrm{~mm}$ of precipitation, and an eroded material rate of $347.8 \mathrm{~g} / \mathrm{l}$, totalizng $24.18 \mathrm{~kg} / \mathrm{m}^{2} /$ year. Meanwhile, pasture had volumes of $6,667 \mathrm{~mm}$, eroded material rate of $215.8 \mathrm{~g} / \mathrm{l}$, and total eroded material of $25.91 \mathrm{~kg} / \mathrm{m}^{2} /$ year. In both areas the type of material displaced is represented first by the sand, followed by the clay and, in smaller volume, by the silt.

Keywords: Laminar erosion. Tenente Amaral River. Gerlach gutters.

\section{ANÁLISIS DE LA EROSIÓN LAMINAR EN ÁREAS CON USO AGRÍCOLA Y PASTIZALES: CUENCA HIDROGRÁFICA DEL RIO TENENTE AMARAL - MT}

Resumen: El sistema hidrográfico del rio Tenente Amaral tiene su área inserida en la unidades morfoculturales de la depresión Interplanáltica de Rondonópolis y del Planalto y la Chapada dos Guimarães. El trabajo presenta los resultados del monitoreo de desplazamiento de material por erosión superficial en dos

\footnotetext{
${ }^{1}$ Universidade Federal de Mato Grosso, Departamento de Geografia, Cuiabá-MT, Brasil, clebersonjesuz@ufmt.br, https://orcid.org/0000-0002-5782-070X

2Universidade Federal de Mato Grosso, Departamento de Geografia, Cuiabá-MT, Brasil, ivanizacabral@hotmail.com, https://orcid.org/0000-0002-0844-180X
} 
experimentos situados en área de pastos y agricultura de Planalto. En el período el área con agricultura presentó un acumulado de $7.026 \mathrm{~mm}$ de precipitación, y la tasa de material erosionado de $347,8 \mathrm{~g} / \mathrm{l}$, totalizando $24,18 \mathrm{~kg} / \mathrm{m}^{2} / a n ̃ o$. En cuanto, el pastizal tuvo volúmenes de $6.667 \mathrm{~mm}$, la tasa de material erosionado de 215,8 $\mathrm{g} / \mathrm{l}$, y total de material erosionado de $25,91 \mathrm{~kg} / \mathrm{m}^{2} / a n ̃ o$. En ambas las áreas, el tipo de material desplazado está representado por la arena en primer lugar, seguido por la arcilla y, en menor volumen, el limo.

Palabras clave: Erosión laminar. Rio Tenente Amaral. Canales de Gerlach.

\section{Introdução}

O ritmo de alterações da natureza vem alastrando fenômenos de desequilíbrio entre os ambientes e, consequentemente, afetando a vida humana direta e/ou indiretamente, por meio de desastres ambientais, propagação de vetores de doenças, desequilíbrios de temperatura e pluviosidade local e regional, entre outras consequências (DREW, 1986; ROSS, 1995; MOREL, 2004; LAMBIN et al., 2013).

No caso do Brasil, a principal base natural que sustentou esse processo colonizador tardio foi, e ainda é, em sua grande maioria, o sistema biogeográfico do Cerrado (CHAVEIRO e BARREIRAS, 2010), que de modo consequencial (aspectos naturais), e atrelado aos investimentos tecnológicos (indução/propagação por biotecnologia, maquinários, insumos e aportes financeiros nacionais/internacionais), apresentou condições edáficoclimáticas, físico-bióticas e vegetacionais propícias à consolidação dessa região no sistema produtivo agropastoril nacional de commodities (soja, milho, algodão, eucalipto, carnes bovino-suína, aves e, a canade-açúcar). Não por acaso, este bioma recebeu a alcunha de "celeiro do mundo" (FERREIRA, 2009; CASTILHO, 2007; SILVA et al., 2013).

Neste contexto, o estado de Mato Grosso se firma nos últimos anos como grande referência na consolidação desse modelo de produção, especialmente por apresentar as unidades de paisagem com características geoambientais favoráveis à elevada produção agropastoril exigida pelo mercado, isto é, condições climáticas e morfopedológicas, sendo massiva a exploração das áreas dos Planaltos e Chapadas dos Guimarães e Parecis, porção centro-leste e centro-norte do Estado.

As superfícies destas duas unidades morfoesculturais são amplamente utilizadas para a prática agrícola e bovinocultura extensiva de corte em larga escala, com amplo emprego da tecnologia, pois as condições edafoclimáticas e morfométricas que compõem o quadro das unidades de paisagem destas áreas são os maiores atrativos para o setor do agronegócio em escala nacional e internacional. 
Em linhas gerais, estas áreas fazem parte de um contexto de superfícies que apresentam certa estabilidade frente à ação dos agentes promovedores da perda do potencial produtivo dos solos. Topograficamente são as áreas de interflúvios com grandes extensões, recobertos por perfis de solos com boas condições físicas, e distribuição das chuvas em meses bem definidos ao longo dos ciclos hídricos, tanto que o calendário agrícola nessas áreas é definido pelo início e rotação de culturas, começando em final setembro ou começo de outubro, rotacionando em fevereiro/março, e encerrando-se nos meses de junho/julho, permanecendo os meses de agosto e a primeira quinzena de setembro para o período do vazio sanitário da soja e do algodão.

Esse modelo de produção sintonizando as condições pluviométricas e calendário de produção agrícola acirra ainda mais a produção de sedimentos, provenientes dessas áreas (degradacionais) para as morfoesculturas de menor altitude, casos da Depressão Cuiabana e da Planície do Pantanal (deposicionais), pois regionalmente o nível de base e o grande sistema agradacional dos sedimentos oriundos das superfícies mais elevadas da porção do centro-sul do Estado (Planalto e Chapada dos Guimarães, Cinturão Orogênico Paraguai-Araguaia, e Suíte Intrusiva Serra de São Vicente), é o Pantanal em sua extensão setentrional.

Dessa forma, o objetivo da pesquisa foi estabelecer uma análise sobre a relação entre dados pluviométricos e o volume de sedimentos em áreas de agricultura mecanizada e pecuária extensiva em uma parcela do setor do alto curso da bacia hidrográfica do rio Tenente Amaral. $O$ trabalho foi desenvolvido em duas parcelas situadas em cabeceiras de nascentes de rios, onde foram instaladas seis estações experimentais do tipo Calhas de Gerlach e monitoradas durante o período de 2013 a 2014.

\section{REVISÃO BIBLIOGRÁFICA}

\section{Solos e o seu significado}

O solo é um dos elementos fundamentais para sobrevivência humana, pois como afirma Amaral (1984, p. 18), "o homem se encontra na bifurcação do destino: ou tratará bem o solo, que, fecundo, alimentará a humanidade, ou, submetendo-o à aventura do domínio egoístico, fará com que sejam deglutinados os insensatos".

Sua conceitualização entre as diversas linhas de trabalho, não são unânimes, isto é, há sempre muitas formas de se considerar o solo, principalmente levando em 
conta sua aplicação e método de análise. Dessa forma, Curi et al., (1993) aborda que o solo é a coleção de corpos naturais na superfície da Terra. Enquanto, Baize et al., (1990), discorre sobre esse contínuo na paisagem (o solo), interrompido apenas por afloramentos rochosos, águas espessas e geleiras.

Sendo que, é denominado por alguns pedólogos de cobertura pedológica, e Jenny (1941) aponta ser ele um resultado da ação combinada dos fatores de formação: clima, relevo, material de origem, tempo, organismos. Ou Simonson (1959), que o atribui aos processos pedogenéticos: adição, perda, transportes seletivos, transformações.

A definição de maior amplitude nos aportes considerados para essa pesquisa é a da Embrapa, (2006, p. 31), onde relata que o solo

[...] é uma coleção de corpos naturais, constituídos por partes sólidas, líquidas e gasosas, tridimensionais, dinâmicos, formados por materiais minerais e orgânicos que ocupam a maior parte do manto superficial das extensões continentais do nosso planeta, contém matéria viva e podem ser vegetados na natureza onde ocorrem e, eventualmente, terem sido modificados por interferências antrópicas.

As ações de depauperamento dos solos causam, atualmente, inúmeros problemas sociais, econômicos e principalmente ambientais. O uso do solo praticado vai de encontro com os ideais necessários, pois hoje, as práticas provocam destruição da vegetação natural, expondo os solos diretamente a uma série de fatores que, associados às suas características físico-químicas, ao clima e à topografia, propiciam cada vez mais uma degradação acelerada e praticamente irreversível.

\section{Erosão e seus fatores biofísicos}

Lepsch (2010 p. 181) expõe que os principais fatores de degradação dos solos estão ligados ao mau uso e ineficientes investimentos dos nossos agricultores, que provocam os processos de Lixiviação e Acidificação, Excesso de Sais ou Salinização, Desertificação, Poluição, Degradação Física e a Erosão (hídrica e eólica), o que, segundo o autor, é a mais nociva e que merece uma maior abordagem.

Essa realidade se destaca nos ambientes do Cerrado brasileiro, onde devido aos processos de ocupação e solidificação da economia de primeiro setor, esta avança sobre os recursos naturais de forma mais severa. Pois, conforme Guerra e Botelho (2010, p. 197) explicitam essa problemática para o Planalto Central, onde os 
solos devem ser utilizados com cautela, pois, apesar de apresentarem facilidades para a mecanização, tem sido constatada a ocorrência de ravinas e voçorocas em diversas áreas, relacionadas diretamente à compactação provocada pela passagem das máquinas agrícolas e somado a isso o intenso pisoteio do gado.

Levando em consideração as colocações apresentadas pelos autores, é imprescindível o entendimento da gênese dos processos erosivos e, conforme destaca Bertoni e Lombardi Neto (2012, p. 45), a erosão é "causada por forças ativas, como: as características da chuva, a declividade e comprimento do declive do terreno e a capacidade que tem o solo de absorver água, além da densidade da cobertura vegetal" presente em cada meio.

Sendo assim, para encontrar soluções concretas em relação aos problemas ligados à erosão, é necessário compreender todos os seus fatores contribuintes e suas diferentes interrelações. Quando se busca identificar os principais mecanismos envolvidos nos processos erosivos é necessário analisar as características denominadas de feições erosivas, que podem ser observadas em cortes espaçotemporais, em diferentes graus de atividade e de evolução (OLIVEIRA, 2008).

De forma geral, os mecanismos expressam as características físico-químicas que os condicionam a promover mudanças nas feições das paisagens, sendo derivadas dos caminhos tomados pelo fluxo de água na superfície e/ou subsuperfície. Um dos mecanismos mais atuantes inicia-se pela ação do gotejamento da chuva, denominado de splash erosion, ou erosão por salpico (OLIVEIRA, 2008).

\section{Avaliação de Erosão}

Conforme Guerra (2010, p. 18), o processo erosivo hídrico inicia-se normalmente com o gotejamento das chuvas, fator determinante da erosividade que, em suma, é a habilidade da chuva em causar erosão, proveniente de sua energia cinética. As gotas de chuva, ao bombardearem o solo, provocam a ruptura dos agregados, que é denominado de fator splash ou salpicamento.

Assim, os agregados dispersos através desse fator provocam o surgimento de crostas, que influem no processo de selagem do solo. Com os topos dos solos selados, a ação da força cinética da água se torna inevitável, surgindo pequenas concentrações de poças (ponds) nas imperfeições/depressões do terreno, devido à selagem e ao saturamento do solo, que se desenvolve por falta de capacidade dos seus poros em absorver todo o contingente de água e, muitas vezes, por esse já 
apresentar uma umidade anterior ao evento chuvoso. Deste modo, a infiltração da água no solo é um dos primeiros processos efetivamente ligados ao escoamento superficial - runoff. Ao ponto que se esgota a capacidade de retenção superficial do solo (ponds), a água iniciará seu processo de escoamento, primeiramente em fluxo difuso, ou, como relata Guerra (2010, p. 30), "um escoamento em lençol (sheetflow)". Nesse estágio a erosão é básica, envolvendo somente o transporte individual dos grãos salpicados. Segundo o autor, é no desenvolvimento do fluxo linear (flowline) que temos o estágio evolutivo do escoamento superficial, com o surgimento das microrravinas (micro-rills), devido ao atrito dos materiais carregados e o aprofundamento dos canais criados pelos seus deslocamentos.

No estágio denominado fluxo linear o escoamento superficial ganha incrementos de velocidade, força de abrasão e quantidade de sedimentos carregados que, de acordo com Pruski et al. (2004, p. 9), "[...] além das partículas de solo em suspensão, o escoamento superficial transporta compostos químicos, matéria orgânica, sementes e defensivos agrícolas", condicionando "prejuízos diretos à produção agropecuária", e "também polui os cursos d'água".

Corroborando sobre essa questão, Salomão (2010, p. 255) destaca que a busca pelas medidas mais corretas de controle preventivo e corretivo dos processos erosivos depende muito do entendimento correto dos processos relacionados à dinâmica de funcionamento hídrico dos terrenos. Esse entendimento permite constatar dois importantes eventos iniciais, ou seja: (I) aqueles relacionados aos impactos pelas gotas da chuva nos solos, maximizado quando esse não apresenta cobertura vegetal, promovendo a desagregação e liberação de suas partículas e (II) os referentes à dinâmica provocada pelo escoamento superficial das águas, responsáveis pelo transporte das partículas liberadas.

O conhecimento da gênese erosiva subsidia o entendimento dos efeitos intrínsecos e extrínsecos da erosão acelerada do solo que, de acordo com Brady e Weil (2013, p.552) estão relacionados diretamente à perda de solo.

Essa perspectiva de abordagem expõe apenas um lado da problemática, pois o maior impacto intrínseco é o valor do solo, que depois de erodido e depositado não detém o mesmo valor de seu antecessor, ou seja, a camada superficial fértil do solo é arrastada, expondo uma subsuperfície menos fértil, enquanto o material mineral e orgânico arrastado vai perdendo seletivamente suas características originais. Toda essa conjuntura de mobilidade de sedimentos e nutrientes provoca os dois maiores efeitos extrínsecos presenciados na atualidade: (I) a poluição da água por nutrientes 
em excesso (eutrofização); e (II) a poluição dos corpos d'água através da contaminação tóxica de metais pesados, pesticidas, herbicidas, ou seja, agrotóxicos de modo geral utilizados na agropecuária moderna; além do processo de assoreamento dos rios e outros corpos d'água.

Em relação ao avanço do conhecimento sobre os processos erosivos, Guerra e Mendonça (2012, p.79) destacam que lidar com os processos erosivos de forma a monitorá-los, analisá-los e compreendê-los é uma tarefa muito complexa e longa, pois seu comportamento, especialmente no Brasil, é relacionado às práticas falhas de uso e ocupação da terra. Ainda destacam que uma das melhores formas de estudo sobre essa temática é entendendo-as por meio de análise via bacia hidrográfica, pois como indicam os autores, os solos, a paisagem e as bacias hidrográficas (inputs de energia, provenientes das precipitações, e outputs, ligados à saída de água e sedimentos) são sistemas abertos, apresentando um alto grau de possibilidades de análises.

Enfim, as concepções teórico-metodológicas Sistêmicas e Geossistêmicas são perspectivas de abordagem quando se pretende estudar processos de erosão em meio tropical úmido e quente.

\section{MATERIAIS E MÉTODOS}

\section{Área de estudo}

As seis estações experimentais - parcelas das Calhas de Gerlach - foram instaladas na porção sudoeste da bacia hidrográfica do rio Tenente Amaral, distribuídas em dois blocos, conforme os diferentes tipos de uso, isto é, uma área de pastagem para a Pecuária e a outra com Agricultura mecanizada, organizadas conforme expressa as informações apresentadas no quadro 1 e carta imagem da figura 1 .

Quadro 1: Localização dos locais onde foram instaladas as estações experimentais.

\begin{tabular}{|c|c|c|c|c|}
\hline \hline PONTOS & COORDENADAS & $\begin{array}{c}\text { ALTITUDE } \\
(\mathbf{m})\end{array}$ & $\begin{array}{c}\text { USO DA } \\
\text { TERRA }\end{array}$ & TIPOS DE SOLOS \\
\hline \hline PE 01 & $\begin{array}{c}16^{\circ} 02^{\prime} 15^{\prime \prime} \mathrm{S} \\
55^{\circ} 15^{\prime} 01^{\prime \prime} \mathrm{W}\end{array}$ & 646 & Pastagem & $\begin{array}{c}\text { Latossolo Vermelho } \\
\text { Amarelo textura } \\
\text { arenosa }\end{array}$ \\
\hline PE 02 & $\begin{array}{c}16^{\circ} 02^{\prime} 16^{\prime \prime} \mathrm{S} \\
55^{\circ} 15^{\prime} 03^{\prime \prime} \mathrm{W}\end{array}$ & 651 & Pastagem & $\begin{array}{c}\text { Latossolo Vermelho } \\
\text { Amarelo textura } \\
\text { arenosa }\end{array}$ \\
\hline
\end{tabular}




\begin{tabular}{|c|c|c|c|c|}
\hline PE 03 & $\begin{array}{c}16^{\circ} 03^{\prime} 00^{\prime \prime} \mathrm{S} \\
55^{\circ} 15^{\prime} 03^{\prime \prime} \mathrm{W}\end{array}$ & 659 & Pastagem & $\begin{array}{c}\text { Latossolo Vermelho } \\
\text { Amarelo textura } \\
\text { arenosa }\end{array}$ \\
\hline PE 04 & $\begin{array}{c}16^{\circ} 03^{\prime} 12^{\prime \prime} \mathrm{S} \\
55^{\circ} 17^{\prime} 00^{\prime \prime} \mathrm{W}\end{array}$ & 699 & Agricultura & $\begin{array}{c}\text { Latossolo Vermelho } \\
\text { textura arenosa }\end{array}$ \\
\hline PE 05 & $\begin{array}{l}16^{\circ} 03^{\prime} 12^{\prime \prime} \mathrm{S} \\
55^{\circ} 17^{\prime} 05^{\prime} \mathrm{W}\end{array}$ & 699 & Agricultura & $\begin{array}{c}\text { Latossolo Vermelho } \\
\text { textura arenosa }\end{array}$ \\
\hline PE 06 & $\begin{array}{l}16^{\circ} 03^{\prime} 12^{\prime \prime} \mathrm{S} \\
55^{\circ} 17^{\prime} 02 \text { 'W }\end{array}$ & 688 & Agricultura & $\begin{array}{c}\text { Latossolo Vermelho } \\
\text { textura arenosa }\end{array}$ \\
\hline \hline
\end{tabular}

Fonte: Pesquisa de campo.

Figura 1: Localização das parcelas experimentais na Bacia Hidrográfica do rio Tenente Amaral - MT.

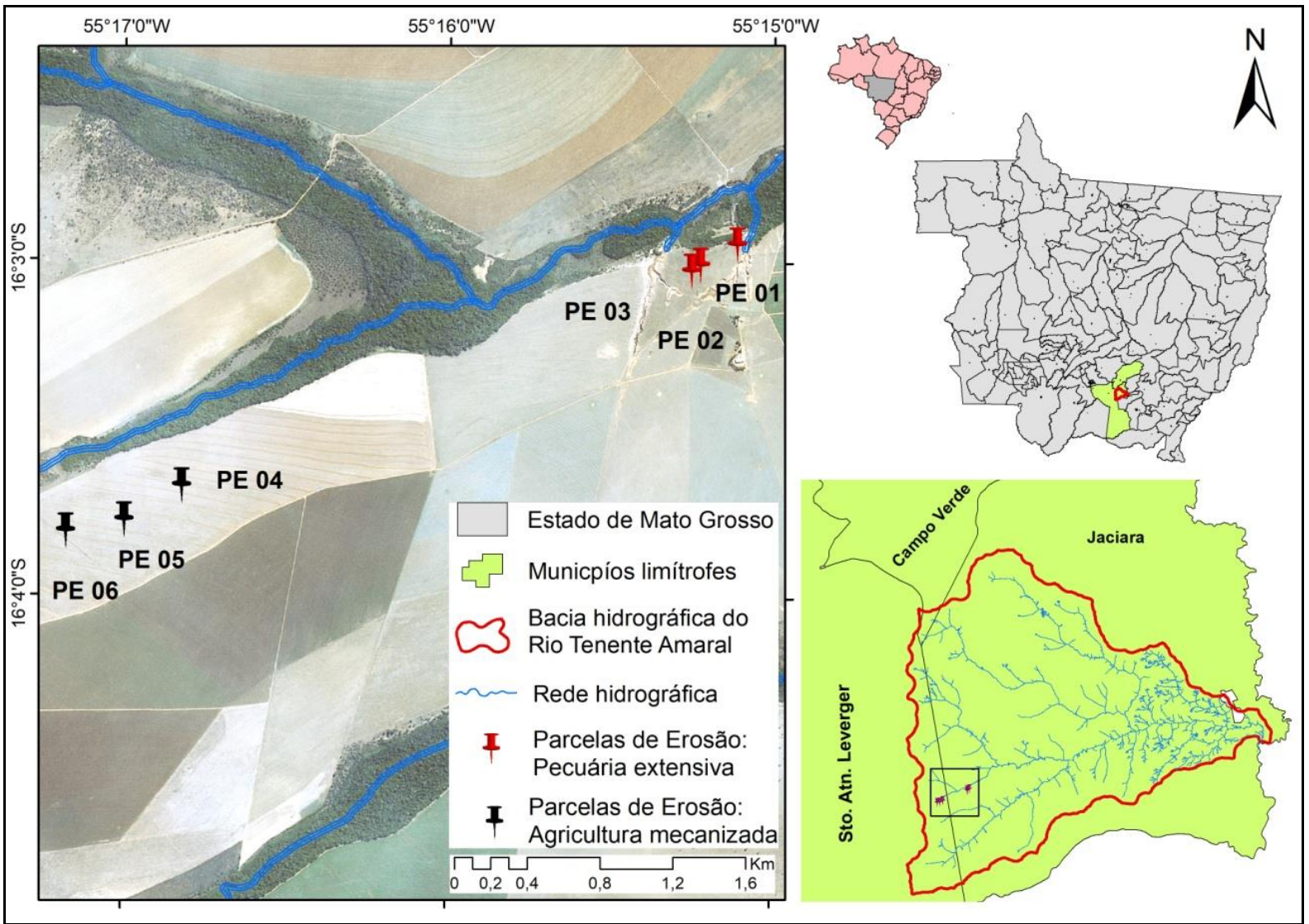

Elaboração: Autores.

As condições naturais associadas ao processo de colonização/ocupação da região em meados dos anos de 1940 e 1950 promoveram uma série de mudanças nas unidades de paisagem que perfazem o quadro natural original da bacia hidrográfica do rio Tenente Amaral (JESUZ, 2014, p. 25). O viés produtivo principal enquadra-se na agricultura mecanizada - soja, milho, algodão e cana-de-açúcar 
(agroindústria), na pecuária extensiva de corte e de base leiteira e uma pequena parte na produção de mantimentos de subsistência - mandioca (farinha).

A área, onde foram instaladas as parcelas experimentais são espaços de atividades ligadas à pecuária bovina extensiva e agricultura mecanizada. A primeira encontra-se, principalmente, na porção sul, sudeste e nordeste da área da bacia hidrográfica em questão e, de acordo com Barros (2011, p.84) essa prática abrange cerca $33 \%$ do total da área da bacia hidrográfica. Por outro lado, $42 \%$ da área da bacia é destinada ao cultivo do milho, cana-de-açúcar, algodão e a soja, situadas também nas porções sul, sudoeste, norte e noroeste da mesma.

Contextualizando a questão do uso na região é importante destacar que entre os anos de 2002 a 2014 o WWF-Brasil criou um programa chamado "Monitoramento das Alterações da Cobertura Vegetal e Uso do Solo na Bacia Hidrográfica do Alto Paraguai - BAP (porção brasileira)", visando acompanhar os processos de supressão da cobertura vegetal e conversão de áreas em lavouras nas superfícies de cabeceiras dos sistemas de drenagem da parte Pantanal Setentrional (WWF, 2015).

O levantamento realizado por esse programa indica que durante o período monitorado pelo mesmo, a área da bacia hidrográfica do rio Tenente Amaral teve acréscimos nas parcelas destinadas à produção agropastoril, em detrimento das Áreas de Preservação Permanente e de Reserva Legal, conforme indica os dados apresentados na tabela 1 .

Tabela 01: A dinâmica sobre uso e ocupação das superfícies na área da bacia hidrográfica do rio Tenente Amaral - MT no período de 2002 a 2014.

\begin{tabular}{lccccc}
\hline Formas de uso e ocupação & \multicolumn{5}{c}{ Área total (km²) } \\
\cline { 2 - 6 } & $\mathbf{2 0 0 2}$ & $\mathbf{2 0 0 8}$ & $\mathbf{2 0 1 0}$ & $\mathbf{2 0 1 2}$ & $\mathbf{2 0 1 4}$ \\
\hline \hline Agricultura & 487 & 495 & 501 & 544 & 559 \\
Pecuária & 141 & 144 & 148 & 105 & 98 \\
Vegetação Natural & 163 & 150 & 147 & 144 & 140 \\
Interferência Urbana & 23 & 23 & 23 & 23 & 24 \\
\hline Outras formas de uso & 17 & 19 & 23 & 15 & 11
\end{tabular}

Fonte: WWF-Brasil, 2015.

Essa condição da ocupação com viés de supressão da cobertura vegetal original e implantação de monoculturas tem relação, entre outros fatores, com as 
características físico-climáticas regionais onde, conforme Tarifa (2011, p. 78), a área de estudo faz parte de um contexto de ambiente sob a influência do Clima Tropical Continental Alternadamente Úmido e Seco das Chapadas, Planaltos e Depressões de Mato Grosso, com médias pluviométricas anuais entre 1650 a 2100 mm.

Em relação ao contexto fitofisionômico original, a área em questão faz parte do conjunto biogeográfico do Cerrado, com predominância de três grandes grupos tipológicos: Formações Savânicas, Formações Florestadas e Vegetações Secundárias (BRASIL, 1982; VASCONCELOS, 1998).

Nesta área, conforme Camargo (2011, p.43), os Latossolos Vermelho e Vermelho-Amarelo, Neossolo Quartzarênico e Argissolo Vermelho-Amarelo constituem os principais tipos de solos. Apresentam textura arenosa devido à composição do seu material de origem, pois as Unidades Litoestratigráficas presentes na área são representadas por componentes rochosos sedimentares e neoformados da borda norte da bacia sedimentar do Paraná, ou seja: a Formação Furnas, Grupo Rio Ivaí, e as Superfícies Paleogênicas Peneplanizadas com Latossolização (VASCONCELOS, 1998; EMBRAPA, 2006).

\section{Procedimentos técnico-operacionais}

Primeiramente, a pesquisa teve suporte na sistemática do pensamento teórico, e a utilização das técnicas de avaliação de erosão laminar, especialmente sobre as Calhas de Gerlach (GONÇALVES et al., 2006; PINESE et al., 2006A, 2006b; RODRIGUES, 2006; ROSS et al., 2011; VALENTE e GOMES, 2005). Desta forma foi possível verificar que o uso de técnicas e metodologias que envolvem acompanhamentos in loco e via experimentos são úteis e de grande rigor científico (BEZERRA et al., 2012; CASSETI, 2005; GARBIN, 2006)

Sendo assim, os procedimentos adotados envolveram cinco fases, sendo as três primeiras em campo, e as duas finais em laboratório e gabinete. A primeira, segunda e terceira fases tiveram início com a avaliação e escolha da área para a instalação dos experimentos, seguida pela execução de trabalhos instalação dos mesmos e elaboração de uma rotina para fazer a coleta de material para análise e limpeza dos experimentos. Nas duas últimas fases foram desenvolvidos os trabalhos em laboratório/gabinete onde foi executada a separação, preparação e análise dos materiais coletados, e seus respectivos tratamentos estatísticos e de preenchimento de banco de dados (Fig. 2). 
Figura 2: Síntese dos procedimentos da metodologia adotada.

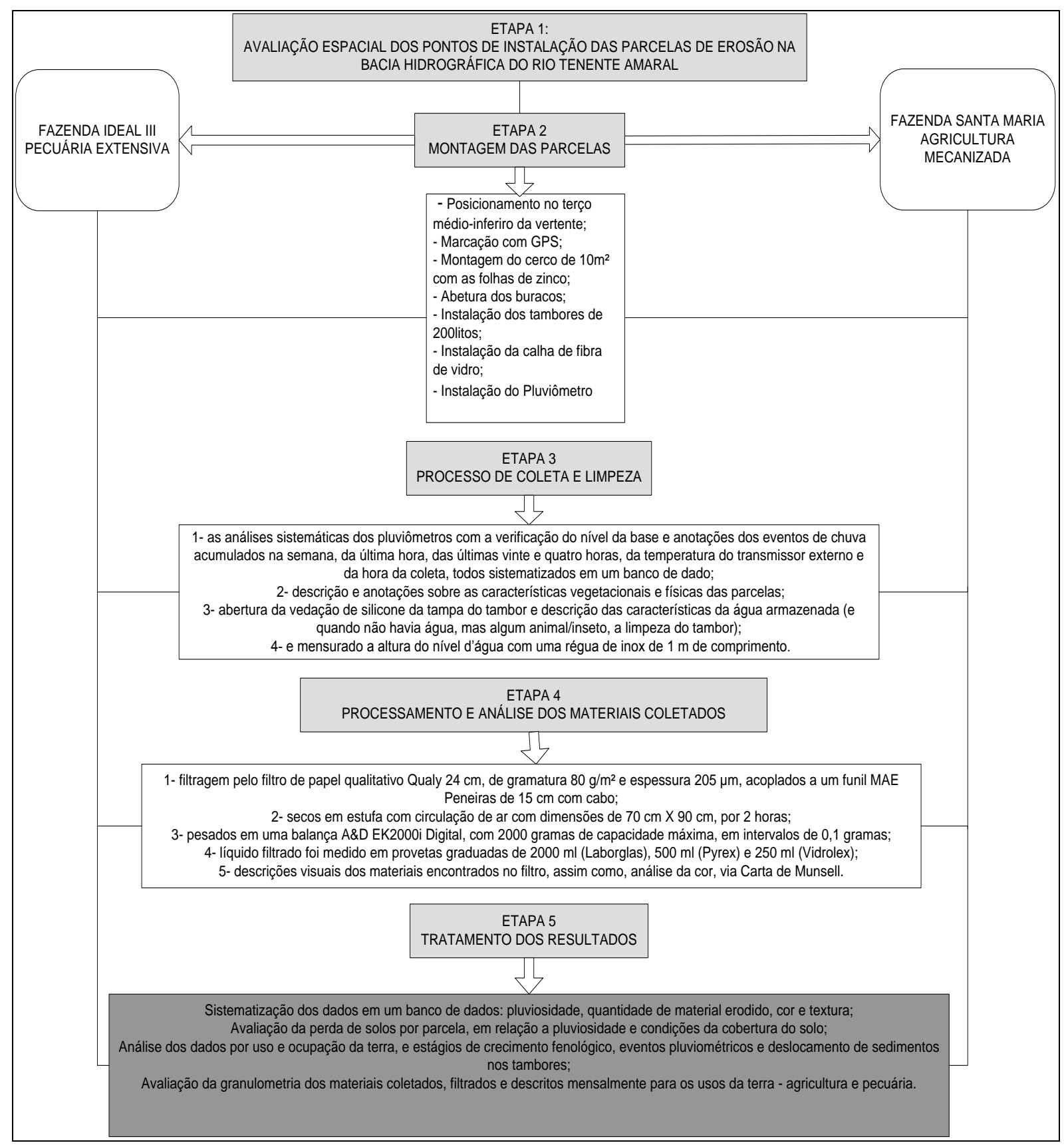

Elaboração: Autores.

Os procedimentos adotados para todas as fases desenvolvidas iniciaram no final de setembro de 2013 e finalizaram em agosto de 2014, totalizando 51 coletas efetivadas em campo.

Estas atividades levaram em consideração um período que abrangesse os ciclos naturais climáticos do Estado e o calendário agrícola adotado pelos agricultores e pecuaristas das áreas onde os experimentos estavam dispostos.

As etapas supracitadas seguiram uma normativa proposta conjuntamente pelos autores, levando em consonância os fatores ambientais e de uso da área, especialmente as etapas 1, 2 e 3, que por serem o cerne dos experimentos exigiram 
várias avaliações e preparação de modelos antes de serem postas em prática.

Esses critérios levaram à fixação de três parcelas de experimentos em área de pecuária extensiva, denominadas de PE01, PE02 e PE03, e mais três em área de agricultura mecanizada, chamadas de PE04, PE05 e PE06, conforme registrado nas imagens da figura 3.

Figura 3: Registro dos procedimentos técnico-operacionais que fizeram parte das etapas 1, 2 e 3 dos trabalhos executados nas parcelas experimentais - montagem; instalação e coleta.

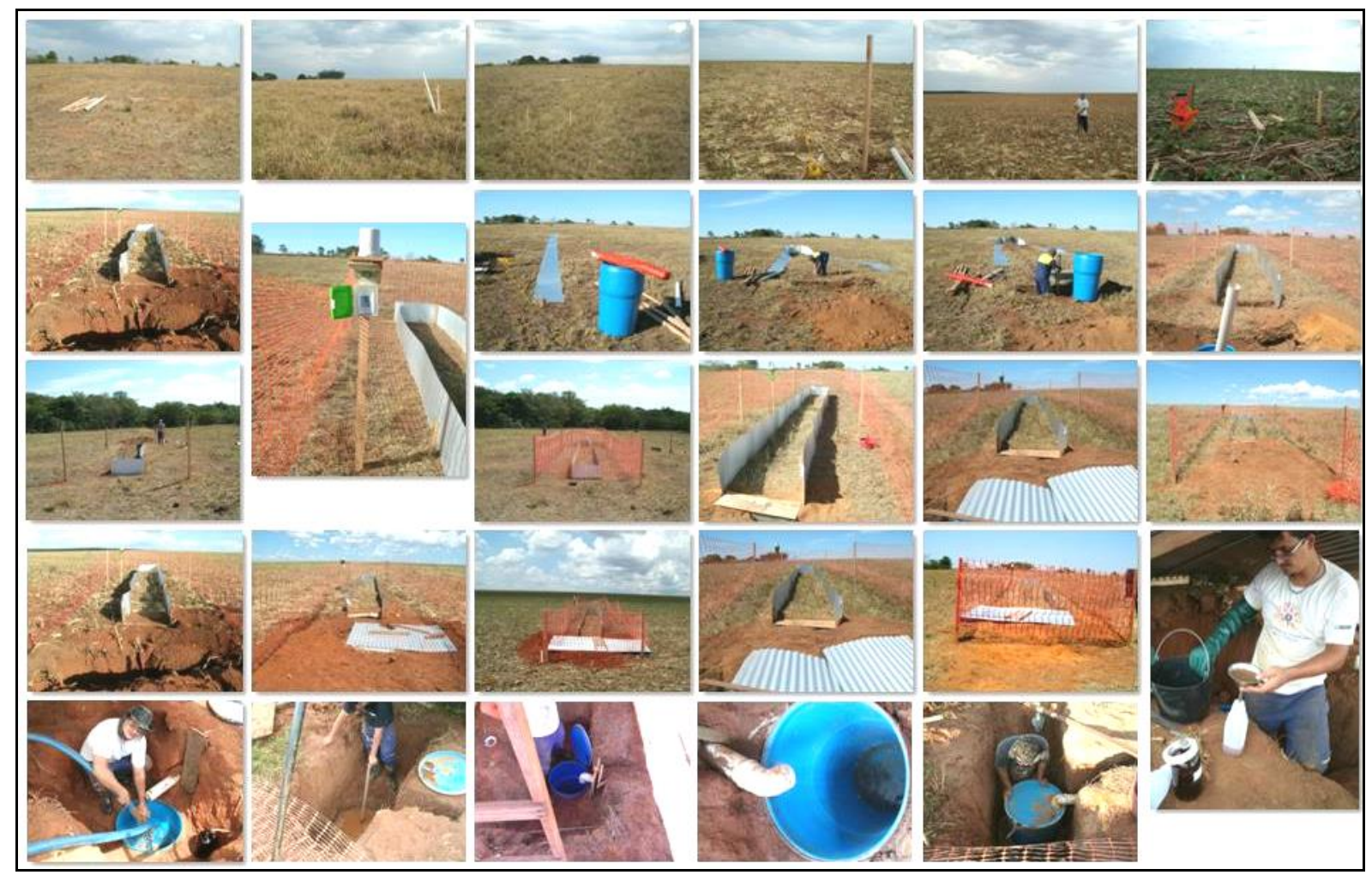

Fonte: Trabalhos de campo. Elaboração: Autores.

Para medir o volume das precipitações ocorridas durante o período analisado foi instalado um pluviômetro junto a cada uma das parcelas experimentais, sendo que o registro dos dados de precipitação e a coleta de material transportado para os tambores foram realizados semanalmente.

Na sequência, etapa 4, tem-se o momento da sistematização e organização dos procedimentos para armazenagem e análises dos materiais coletados em campo, conforme registrado nas cenas da figura 4 . 
Figura 4: Registro das atividades desenvolvidas na etapa 4 - filtragem, secagem, análise e armazenagem de material coletado nas estações experimentais.
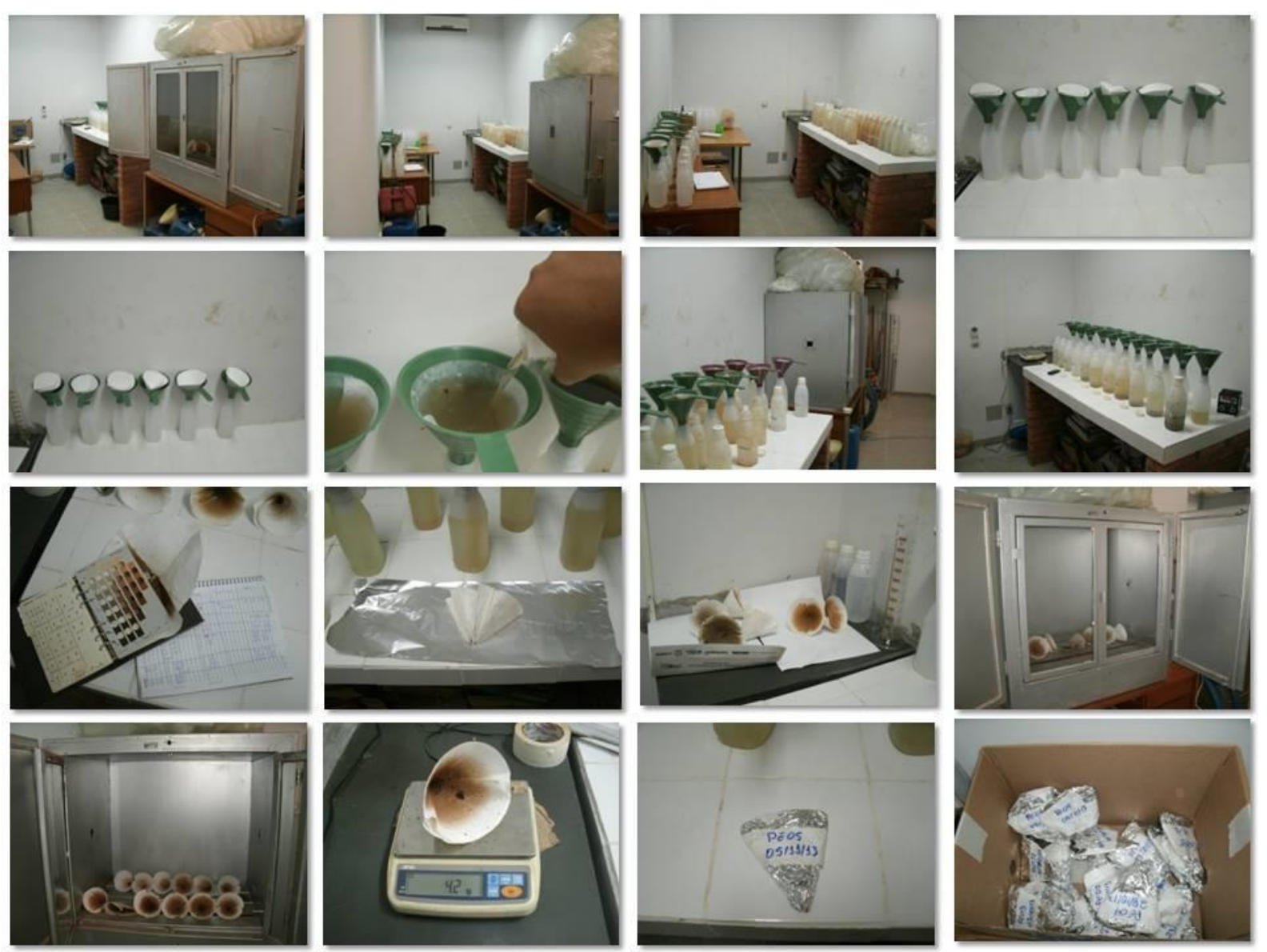

Fonte: Atividade de laboratório. Elaboração: Autores

$\mathrm{Na}$ etapa 5 foram realizados os procedimentos relacionados à quantificação e organização dos dados sobre as informações e os materiais coletados em campo, ou seja, tratamento estatístico dos dados pluviométricos, organização dos dados sobre material erodido e do deslocamento de água superficial. Toda essa etapa foi realizada em gabinete, correspondendo à fase de finalização do experimento.

\section{RESULTADOS E DISCUSSÃO}

Os resultados obtidos pela aplicação da referida metodologia na área em questão apresentam relevância ao se tratar da atual conjuntura da produção primária no Estado, onde a "necessidade" de expansão da produção agropastoril em decorrência da exigência do mercado conflita com os danos em relação à perda da capacidade de produção dos solos, repercutindo, até mesmo, na própria resiliência dos mesmos em relação aos sistemas originais, especialmente em áreas de fragilidade ambiental, ou seja, as superfícies de nascentes. Assim, propõe-se a abordagem dos fatores vislumbrados por dois recortes de uso da terra, a pecuária 
extensiva e agricultura mecanizada, situadas em diferentes condições topográficas, conforme indica o mapa com as curvas de nível de 2 metros apresentado na figura 5.

Figura 5: O contexto topográfico e a localização das parcelas experimentais na Bacia Hidrográfica do Rio Tenente Amaral - MT.

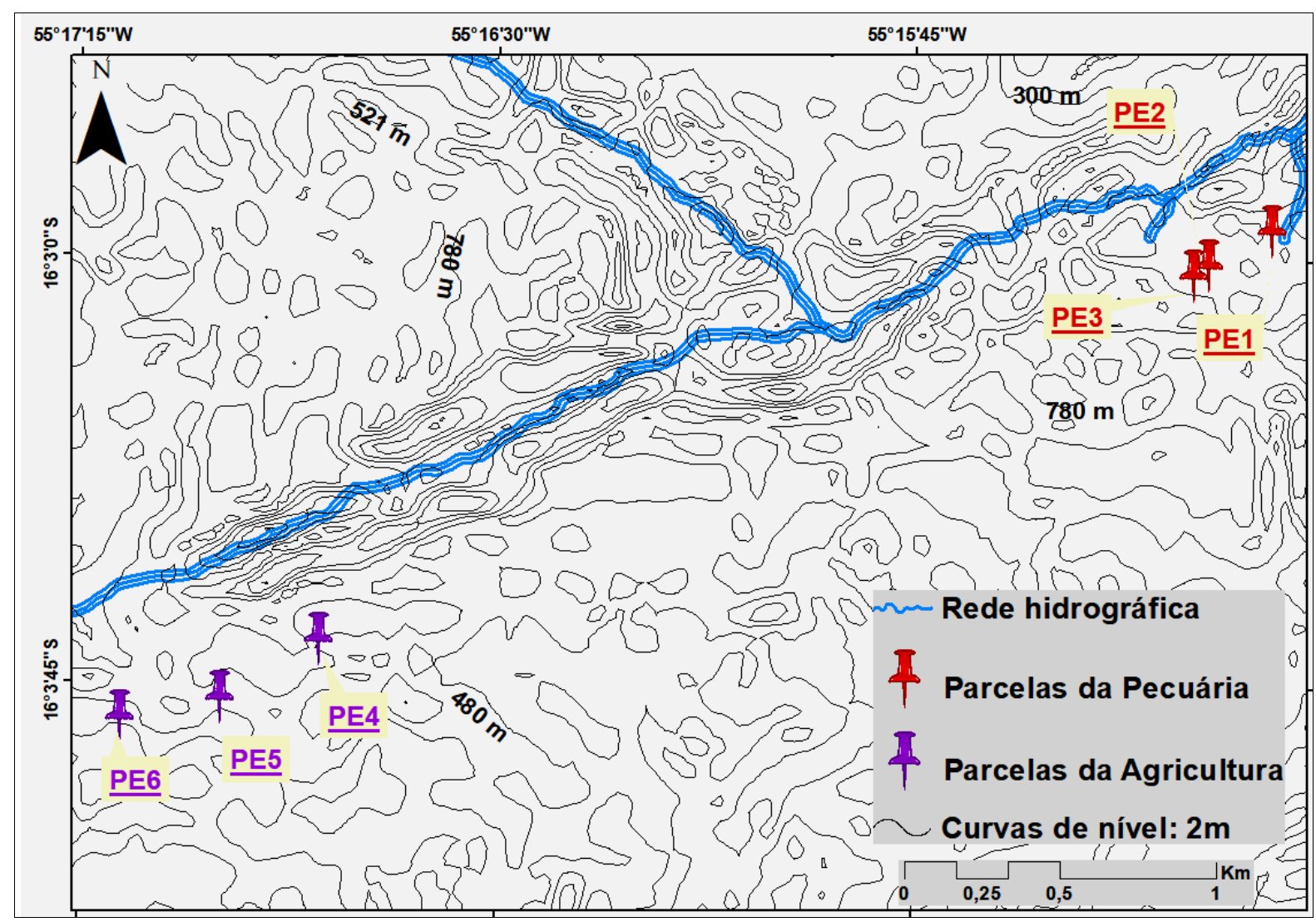

Fonte: SRTM-TOPODATA. Elaboração: Autores.

\subsection{Análise sobre a erosão laminar em uso de pecuária extensiva: Sistema cria/recria/engorda.}

Em primeiro lugar, a produção geográfica dos espaços destinados às atividades primárias de produção no estado de Mato Grosso tem seu suporte nos recursos naturais disponíveis, principalmente relevo, solo e clima. As superfícies destinadas à produção empresarial apresentam diversidade em relação ao seu potencial de produção e as formas de uso fazem adequações em relação a isso. Assim, a sistemática de uso nas áreas da agropecuária empresarial do Estado tem suporte na escala da capacidade produtiva dos solos. A introdução da pecuária nas áreas da agricultura empresarial faz parte da sistemática de intensificação de uso da 
terra, onde as superfícies com solos mais "inferiores" são destinadas a esta atividade.

Por outro lado, a distribuição geográfica destes grupos de solos na região tem relação com a própria morfodinâmica evolutiva do relevo planáltico, onde a diversidade de processos vinculados à variação da condição de "estabilidade das superfícies" expressa as varias condições dos mesmos e o surgimento de outras variedades.

É no contexto da variação das unidades de paisagem que surge a prática da criação extensiva do boi nas áreas de agricultura empresarial, ou seja, as superfícies que apresentarem algum tipo de restrição para o uso agrícola são destinadas a pastagem. $\mathrm{Na}$ área em questão, estas superfícies correspondem aos locais onde os processos geoquímicos e mecânicos decorrentes da ação da água se destacam, refletindo nas condições da pedogênese local/regional.

Geograficamente a prática da pecuária extensiva em consonância e/ou rodízio com a prática da agricultura empresarial vai ocupar as superfícies de menor estabilidade frente aos processos morfodinâmicos, correspondendo às unidades de paisagem dos Neossolos Quartzarênicos, Argissolos, Latossolos Amarelos de textura arenosa, solos hidromórficos com elevada concentração de alumínio.

Sendo assim, os dados registrados nas três estações experimentais sob a condição de uso em questão apresentam disparidades entre as três estações experimentais, conforme indica as informações presentes nos gráficos da figura 6. 
Figura 6: Relação entre os dados pluviométricos e o volume de material superficial transportado nas parcelas experimentais localizadas na superfície de pastagem. PE01, PE02 e PE03, respectivamente.

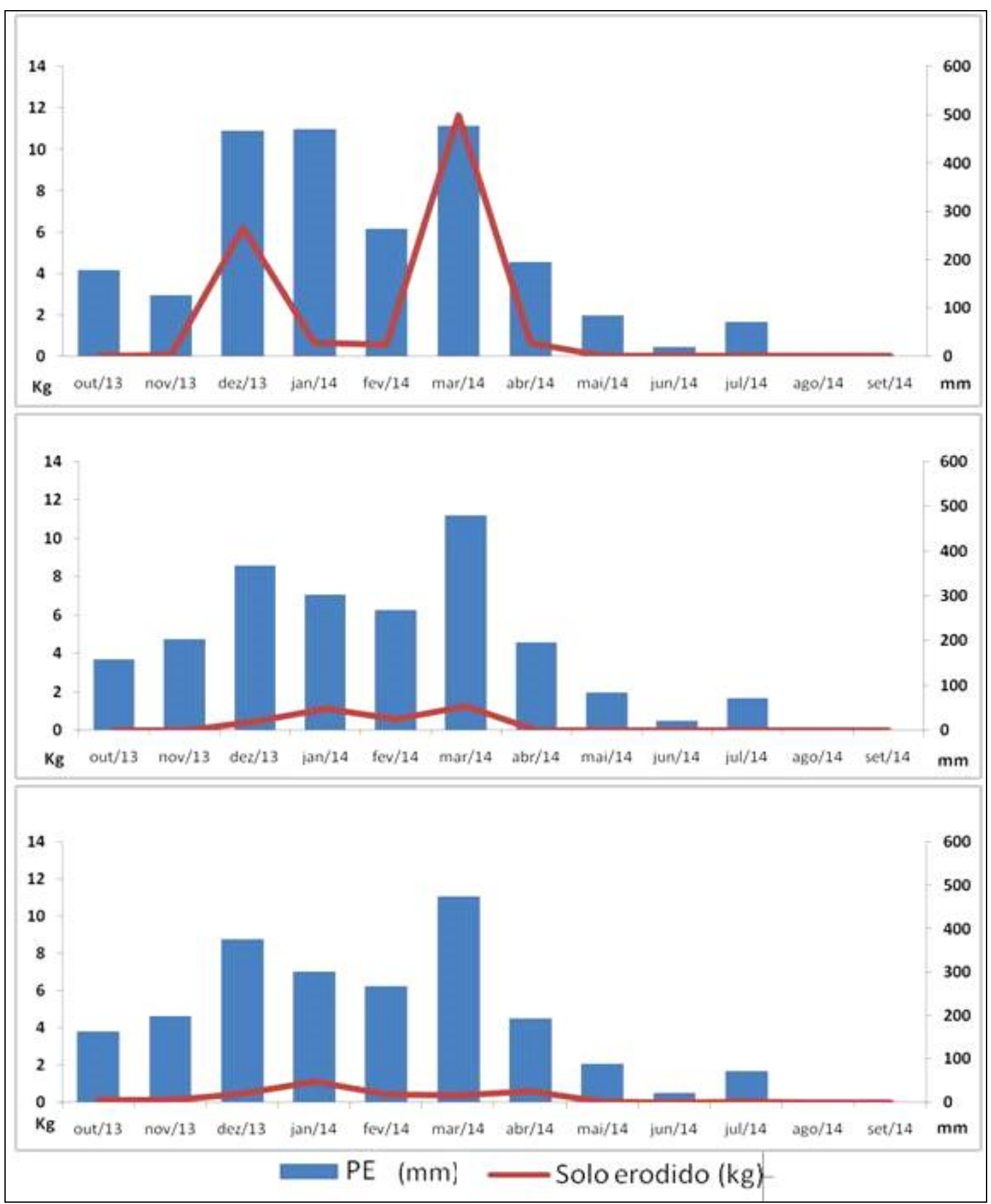

Fonte: Trabalhos de campo. Elaboração: Autores.

Embora os registros do volume das chuvas sejam muito próximos, o deslocamento de material em superfície é diferente, principalmente quando se compara os dados da estação experimental PE01 com as informações registradas nas estações PE02 e PE03. 
No decorrer do período em questão a discrepância registrada na PE01, de aproximadamente cinco vezes os valores registrados nas parcelas PE02 e PE03, mostra a variação da intensidade dos eventos relacionados ao deslocamento de material pelo escoamento superficial ao longo de uma superfície. O volume de material erodido e registrado na PE01 apresenta uma média de 1,64 kg/m², enquanto na PE02 e PE03 os valores são de 0,27 e $0,28 \mathrm{~kg} / \mathrm{m}^{2}$, respectivamente. Na área em questão, entre os vários fatores que explicam tal comportamento, a locação da estação experimental PE01 no setor da vertente, com ocorrência de um evento de voçorocamento próximo, é o fator de maior influencia sobre o volume de material deslocado para o tambor coletor no decorrer da estação das chuvas durante o período analisado.

No entanto, observa-se um comportamento particular em relação ao volume de material deslocado no início e no final da temporada das chuvas nos três locais considerados, isto é, as três estações experimentais registraram pouco material deslocado no início e no final da estação chuvosa. Esse fato tem relação direta com o volume de chuvas precipitado ao longo do período, permitindo inferir que as superfícies na condição de uso pecuário necessitam de maiores volumes de precipitação para desencadear a remoção e o transporte de material ao longo das pendentes do terreno.

Outro fato em destaque na parcela PE01 é a relação direta entre os eventos de maior volume de precipitação e o maior volume de material deslocado para o tambor. Nesta situação é possível inferir que o evento de erosão mecânica, que muitas vezes leva ao desenvolvimento de voçorocas e ravinas, tem relação com o volume e intensidade das chuvas, mesmo em áreas com pastagem, conforme registrado no primeiro gráfico da figura 6 e os dados da tabela 2 .

Tabela 02: Contextualização entre os dados referente a cada uma das estações experimentais em relação ao volume total de material erodido e o volume total de chuvas precipitado no período de 2013/2014 na área com pastagem.

\begin{tabular}{l|l|l|l}
\hline \hline $\begin{array}{l}\text { Parcela } \\
\text { Experimental }\end{array}$ & $\begin{array}{l}\text { Volume total de } \\
\text { precipitação }(\mathbf{m m})\end{array}$ & $\begin{array}{l}\text { Taxa de material } \\
\text { erodido }(\mathbf{g} / \mathbf{l})\end{array}$ & $\begin{array}{l}\text { Volume total de material } \\
\text { erodido }\left(\mathbf{k g} / \mathbf{m}^{2} / \mathbf{a n o}\right)\end{array}$ \\
\hline \hline PE1 & $2.354,1$ & 128,4 & 19,8 \\
\hline PE2 & $2.155,6$ & 29,0 & 3,38 \\
\hline PE3 & $2.157,1$ & 58,4 & 2,69 \\
\hline Total & $\mathbf{6 . 6 6 6 , 7 5}$ & $\mathbf{2 1 5 , 8 3}$ & $\mathbf{2 5 , 9 1}$ \\
\hline \hline
\end{tabular}

FONTE: Levantamentos de campo. Elaboração: Autores. 
3.2 Análise sobre a erosão laminar em uso de agricultura mecanizada: Sistema de rotação de cultivo soja/milho

As informações registradas para as parcelas experimentais da superfície utilizada com agricultura mecanizada apresentam uma contextualização sobre a influência da pluviosidade e o volume do material superficial erodido nas três parcelas experimentais durante o período de realização do experimento, conforme indicam os dados apresentados nos gráficos da figura 7. 
Figura 7: Relação entre os dados pluviométricos e o volume de material superficial transportado nas parcelas experimentais localizadas na superfície de uso agrícola. PE04, PE05 e PE06, respectivamente.

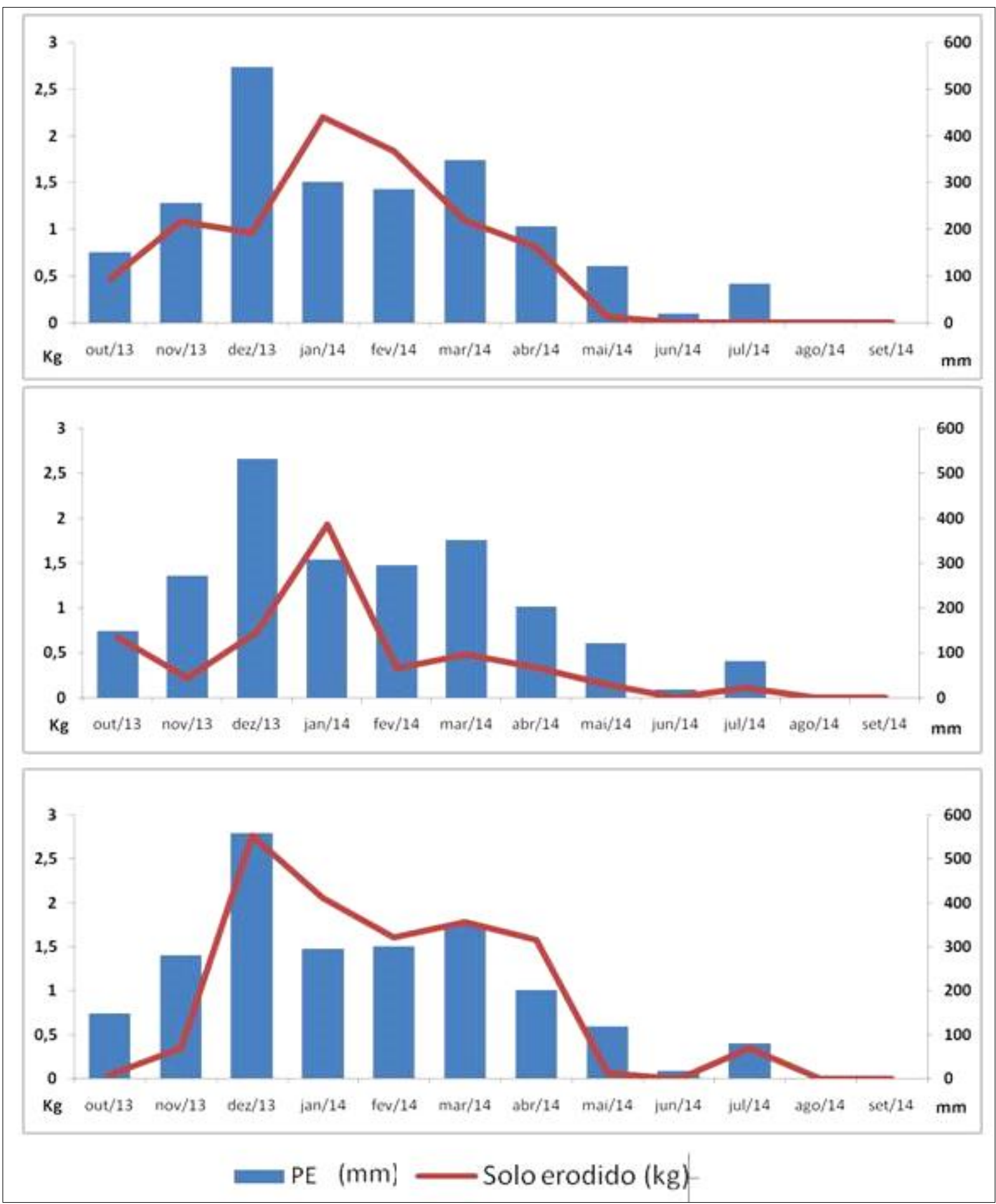

Fonte: Trabalhos de campo. Elaboração: Autores

Inicialmente, cabe destacar que a análise e interpretação dos dados sobre o volume de material sólido deslocado no período foi contextualizado levando em consideração o calendário agrícola e o comportamento extremo das chuvas ao longo 
das estações do ano, bem como a posição do experimento em relação à vertente e aos tipos de solos presentes.

Assim, em termos gerais a quantidade de material nesta condição de uso da terra mostra que os maiores volumes deslocados têm relação com os maiores volumes pluviométricos no decorrer da estação chuvosa. Entretanto, no detalhe são verificadas algumas particularidades como, por exemplo:

I - O volume de material deslocado no início da temporada das chuvas outubro e novembro: Comparando os três locais, verifica-se uma variação em termos de volume de material deslocado, embora o volume de chuvas apresente valores praticamente iguais. Esse fato pode ser decorrente da variação textural dos Latossolos e/ou da posição de cada um dos experimentos na vertente. Particularmente, o PE04 situou-se no setor da ruptura de declive, enquanto que os locais PE05 e PE06 estavam na parte mais elevada e plana. Aqui é importante destacar que essa é a época de plantio, quando as superfícies estão mais expostas e os solos em condição de baixa umidade devido à antecessora estação seca.

\section{II - Alguma discrepância entre o volume de chuvas e o volume de material} transportado: Nota-se que os mais altos índices pluviométricos não estão diretamente ligados aos maiores picos de erosão superficial, podendo ser observados momentos diferentes no transcorrer do período das chuvas, e situações inversas entre as parcelas, em especial a PE05 que no início do período das chuvas apresentou um comportamento diferente das parcelas PE04 e PE06. Os dados obtidos na PE05 expressam um menor volume de material deslocado com um máximo somente no mês de janeiro de 2014. Esse fato pode estar relacionado com a variação textural dos solos devido à variação da topografia da vertente, ou seja, a PE05 foi locada na posição mais "estável" da mesma.

\section{III - A discrepância entre os dados pluviométricos e o volume de material} presente nos tambores de armazenamento: A relativa condição de homogeneização dos volumes pluviométricos registrados nas parcelas experimentais em questão é fato que chama a atenção, pois com valores tão próximos, o total de material armazenado nos tambores também deveria seguir tal condição. Contextualizado em relação a uma área de um metro quadrado é possível averiguar que a parcela PE06 está numa posição da vertente que mais perde material pelo deslocamento superficial, seguida pela PE04, expressando um dos 
setores de baixa estabilidade frente à ação do deslocamento da água de superfície no decorrer de toda a estação chuvosa. Tabela 4 e figura 5.

Tabela 04: Contextualização entre os dados referente a cada uma das estações experimentais em relação ao volume total de material erodido e o volume total de chuvas precipitado no período de 2013/2014 na área com uso agrícola.

\begin{tabular}{l|c|c|c}
\hline \hline $\begin{array}{l}\text { Parcela } \\
\text { Experimental }\end{array}$ & $\begin{array}{c}\text { Volume total de } \\
\text { precipitação } \mathbf{( m m})\end{array}$ & $\begin{array}{c}\text { Taxa de material } \\
\text { erodido } \mathbf{( g / l )}\end{array}$ & $\begin{array}{c}\text { Volume total de material } \\
\text { erodido }\left(\mathbf{k g} / \mathbf{m}^{2} / \mathbf{a n o}\right)\end{array}$ \\
\hline \hline PE4 & $2.325,6$ & 75,70 & 8,62 \\
\hline PE5 & $2.335,1$ & 111,9 & 4,95 \\
\hline PE6 & $2.365,6$ & 160,1 & 10,61 \\
\hline Total & $\mathbf{7 0 2 6 , 3 3}$ & $\mathbf{3 4 7 , 8 1}$ & $\mathbf{2 4 , 1 8}$ \\
\hline \hline
\end{tabular}

FONTE: Levantamentos de campo. Elaboração: Autores.

Os dados evidenciaram diferenças significativas em relação ao processo que envolve o carreamento de material pelo escoamento superficial em ambiente com fatores geoambientais muito próximos. Essas diferenças não podem ser explicadas somente levando-se em consideração a lógica de uso e manejo do solo e sim contextualizando com os fatores ambientais presentes em cada parcela experimental.

Deste modo, uma das questões a ser considerada neste tipo de trabalho é a conjuntura do ambiente onde cada parcela está localizada, pois a mesma sempre vai pertencer a um sistema complexo e diferenciado entre si, mesmo apresentando padrões similares (uso, clinografia, hipsometria, solo e outros) e, devido a isto, sempre apresentarão comportamentos e respostas diversas frente à ação do agente pluvial.

Enfim, o tipo de material deslocado pelo escoamento superficial tem relação direta com as características do material que compõe os solos. Comparando o tipo de material transportado e acumulado nos tambores de cada uma das estações experimentais, tabela 5 , nota-se que houve um deslocamento maior de material na fração argila, seguido pela areia e silte, respectivamente. Entretanto, pelas razões já apresentadas anteriormente, a área de pastagem perdeu mais material arenoso do que a área de agricultura. 
Tabela 05: Características dos materiais depositados nos tambores das estações experimentais durante o período de 2013/2014.

\begin{tabular}{l|c|c|c}
\hline \hline \multirow{2}{*}{ Forma de uso } & \multicolumn{3}{|c}{ Tipo de material depositado (\%) } \\
\cline { 2 - 4 } & Areia & Silte & Argila \\
\hline \hline Área com pastagem & 56,9 & 10,4 & 32,5 \\
\hline Área com agricultura & 39,7 & 13,4 & 46,9 \\
\hline \hline
\end{tabular}

FONTE: Levantamentos de campo. Elaboração: Autores.

\section{Considerações Finais}

A pesquisa teve como meta analisar a dinâmica do deslocamento de material pelo escoamento superficial em duas situações rotineiras de uso nas superfícies do Planalto dos Guimarães no decorrer da estação das chuvas. Os resultados do monitoramento efetivado expressam uma pequena amostra da morfodinâmica superficial sob condição de uma rotina de intervenção bastante típica nesta parte do Estado.

Em relação às medidas efetuadas sobre a erosão laminar promovida pela água das chuvas em áreas destinadas à pecuária e agricultura, os dados coletados durante o período servem para uma primeira avaliação da dinâmica de deslocamento de material pelo escoamento superficial na superfície do Planalto Dissecado dos Guimarães-MT.

Quanto ao método de coleta de sedimentos e água em reservatórios, deve-se levar em consideração que este apresenta uma margem de erro já no ato de efetivar a coleta da amostra de água no reservatório. Por mais habilidade adotada no procedimento sempre haverá um perda de material devido à velocidade de sedimentação no reservatório. Outro fator é o deslocamento de material por rolamento que possivelmente vai apresentar momentos diferentes de armazenamento no reservatório, mas que também fazem parte do processo.

A relação entre os índices pluviométricos e o volume de material deslocado pelo processo de erosão superficial apresentaram certa discrepância ao longo de todo o período, pois os meses que tiveram maiores volume de chuvas nem sempre coincidem com os meses que registraram maiores volumes de material deslocado, sendo possível observar quatro momentos distintos: (I) meses de inicio das chuvas e aumento gradual na produção de sedimentos que vai da segunda quinzena do mês de setembro, até final de dezembro. Este período registra um baixo volume de 
material erodido tanto na área da pecuária, quanto na da agricultura; (II) os meses com maior intensidade pluviométrica tiveram uma melhor distribuição em relação ao volume de material transportado para os reservatórios, principalmente nas superfícies ocupadas pela agricultura, correspondendo ao período dos meses de dezembro, janeiro e fevereiro; (III) meses com declínio nos índices pluviométricos e diminuição do volume de material deslocado, exceto a parcela P1 que está sob efeito de processos de voçorocamento. Este período corresponde aos meses de março, abril, maio e junho, e (IV) diminuição significativa no volume das chuvas e do volume de material deslocado nos meses de maio, junho, julho, agosto e setembro em ambas as áreas, com uma exceção do dia 30/07/2014 de registro pluviométrico elevado e presença de material somente no reservatório PE06.

Enfim, os trabalhos de monitoramento para avaliar a dinâmica de deslocamento de material superficial por ação das chuvas, com suas respectivas formas de uso são importantes para avaliar as transformações impostas às diferentes unidades de paisagem que perfazem o Planalto Dissecado dos Guimarães. O seu desenvolvimento traz consigo a idéia de um "mito" sobre a sua destacada condição de estabilidade frente ao agente pluvial, algo muito utilizado na propaganda sobre o potencial das superfícies planálticas no Estado.

\section{REFERÊNCIAS}

AMARAL, N. D. Noções de conservação do solo. - 2ª . ed. - São Paulo: Nobel, 1984.

BAIZE, D.; GIRARD, M. C.; BOULAINE, J.; CHEVERRY, C. L.; RUELLAN, A. Um referencial pedológico. Por quê? In: Présentation du Referenciel Pedologique au Congres International de Science du Sol. Afes. 1990. p. 45-57.

BARROS, A. O. Aplicabilidade da lógica Fuzzy para classificação do uso da terra na bacia do rio Tenente Amaral em Jaciara/MT. 2011. 101 fls. Dissertação (mestrado em Geografia) - Universidade Federal de Mato Grosso, Instituto de Ciências Humanas e Sociais, Programa de Pós-Graduação em Geografia, Cuiabá, 2011.

BERTONI, J.; LOMBARDI NETO, F. Conservação do Solo. - 8ª . ed. - São Paulo: Ícone, 2012.

BEZERRA, J. F. R; GUERRA, A. T. J; RODRIGUES, S. C. Variação da umidade superficial do solo em parcelas experimentais com uso de geotêxtis biodegradáveis, Uberlândia - MG. Revista Brasileira de Geomorfologia, v.13, n.1, (Jan-Mar) p.93100, 2012.

BRADY, N. C.; WEIL, R. R. Elementos da natureza e propriedades dos solos. (Tradução Técnica: Igo Fernando Lepsch). - 3aㅡ ed. - Porto Alegre: Bookman, 2013.

BRASIL. DEPARTAMENTO NACIONAL DA PRODUÇÃO MINERAL. PROJETO RADAMBRASIL. Folha SD. 21. Cuiabá. Rio de Janeiro, 1982.

CAMARGO, L (Org.). Atlas de Mato Grosso: abordagem socioeconômicoecológica.

Cuiabá - MT: Entrelinhas, 2011. 
CASSETI, V. Geomorfologia. [S.I.]: [2005]. Disponível em:

<http://www.funape.org.br/geomorfologia/>. Acesso em abril de 2017.

CASTILLO, R. Agronegócio e Logística em Áreas de Cerrado: expressão da agricultura científica globalizada. Revista da ANPEGE. v. 3, p. 33 - 43, 2007.

CHAVEIRO, E. F.; BARREIRA; C. C. M. A. Cartografia de um pensamento de Cerrado. In: PELÁ, M.; CASTILHO, D. (orgs.). Cerrados: perspectivas e olhares. - Goiânia. Editora Vieira, 2010.

CURI, N.; LARACH, J. O. I.; KÄMPF, N.; MONIZ, A. C.; FONTES, L. E. F. Vocabulário de ciência do solo. - Campinas: SBCS, 1993. 90p.

DREW, D. Processos interativos Homem-Meio Ambiente. (Tradução: João Alves dos Santos. Revisão: Suely Bastos). - São Paulo: DIFEL, 1986.

EMPRESA BRASILEIRA DE PESQUISA AGROPECUÁRIA - EMBRAPA. Sistema Brasileiro de Classificação de Solos - SBCS. [Editores Técnico: SANTOS, H. G. et. al.]. 2ª ${ }^{\text {a }}$ ed. - Rio de Janeiro: EMBRAPA SOLOS, 2006.

FERREIRA, M. E. Modelagem da dinâmica de paisagem do cerrado. 2009. fls. 115. Tese (Doutorado) - Universidade Federal de Goiás. Pró-Reitoria de Pesquisa e Pós-Graduação. Programa Multidisciplinar de Doutorado em Ciências Ambientais, 2009.

GARBIN, E.J; PINESE, J.F.J; RODRIGUES, S.C. Análise da variação da umidade em diferentes tipologias de uso da terra através do uso de parcelas de erosão. Fazenda Experimental do Glória, Uberlândia - MG. In. VI Simpósio Nacional de Geomorfologia/Regional Conference on Geomorphology: Geomorfologia Tropical e Subtropical: processos, métodos e técnicas. Goiânia, 6 a 10 de Setembro de 2006. Anais 149.

GONÇALVES, D. B; VALE P. N. C; RODRIGUES, S. C. Estudo comparativo entre dados de precipitação e escoamento superficial em parcelas experimentais na Fazenda Experimental do Glória - Uberlândia - MG. In. VI Simpósio Nacional de Geomorfologia/Regional Conference on Geomorphology: Geomorfologia Tropical e Subtropical: processos, métodos e técnicas. Goiânia, 6 a 10 de Setembro de 2006. Anais 504.

GUERRA, A. J. T. O início do processo erosivo. In: GUERRA, A. T. J.; SILVA, A. S.; MACHADO, R. G. (Orgs.). Erosão e conservação dos solos: conceitos, temas e aplicações. 6 $6^{\underline{a}}$ ed. - Rio de Janeiro: Bertrand Brasil, 2010.

GUERRA, A. J. T.; BOTELHO, R. G. M. Erosão dos Solos. In: CUNHA, S. B.; GUERRA, A. J. T. (Orgs.). Geomorfologia do Brasil. - 6ª . ed. - Rio de Janeiro: Bertrand Brasil, 2010.

GUERRA, A. J. T.; MENDONÇA, J. K. S. Erosão dos Solos e a Questão Ambiental. In: VITTE, A. C.; GUERRA, A. T. J.. (Orgs.). Reflexões sobre geografia física no Brasil. $6^{\underline{a}}$ ed. - Rio de Janeiro: Bertrand Brasil, 2012.

JENNY, H. Factors of soil formation. NewYork: McGraw-Hill. 1941. 281p.

JESUZ, C. R. Estudo geomorfológico e a análise dos processos de erosão mecânica na bacia hidrográfica do rio Tenente Amaral - MT. 2014, fls. 142. Dissertação (Mestrado em Geografia) - Universidade Federal de Mato Grosso, Cuiabá, 2014

LAMBIN, E. F.; GIBBS, H. K.; FERREIRA, L., GRAU, R.; MAYAUX, P.; MEYFROIDT, P.; MORTON, D. C.; RUDEL, T. K.; GASPARRI, I.; MUNGER, J. Estimating the world's potentially available cropland using a bottom-up approach.Global Environmental Change-Human and Policy Dimensions. 23 (5): 892-901, 2013.

LEPSCH, I. F. Formação e Conservação dos Solos. - 2ª ed. - São Paulo: Oficina de Textos, 2010 
MOREL, C. M. A pesquisa em saúde e os objetivos do milênio: desafios e oportunidades globais, soluções e políticas nacionais. Ciência \& Saúde Coletiva, 9(2):261-270, 2004.

OLIVEIRA, J. B. Pedologia Aplicada. 3‥ ed. Piracicaba: FELAQ, 2008.

PINESE, J. F. J; CAMPOS, P. I. O; GARBIN, E.J; VALE, P.N.C. Análise do transporte de sedimentos relacionado ao escoamento superficial em parcelas de erosão na Fazenda Experimental do Glória, Uberlândia - MG. In. VI Simpósio Nacional de Geomorfologia/Regional Conference on Geomorphology: Geomorfologia Tropical e Subtropical: processos, métodos e técnicas. Goiânia, 6 a 10 de Setembro de 2006a. Anais 004.

PINESE, J. F. J; GARBIN, E. J; RODRIGUES, S. C. Análise do transporte de sedimentos com diferentes tipos de uso do solo em Calhas de Gerlach (1966) na Fazenda Experimental do Glória, Uberlândia - MG. In. VI Simpósio Nacional de Geomorfologia/Regional Conference on Geomorphology: Geomorfologia Tropical e Subtropical: processos, métodos e técnicas. Goiânia, 6 a 10 de Setembro de 2006b. Anais 154.

PRUSKI, F. F.; BRANDÃO, V. S.; SILVA, D. D. Escoamento Superficial. 2ª ed. - Viçosa: UFV, 2004

RODRIGUES, C.; ADAMI, S. F. Técnicas de Hidrografia. In. VENTURI, Luís Antônio Bittar. (Org.). Geografia: práticas de campo, laboratório e sala de aula. - São Paulo: Editora Sarandi, 2011.

ROSS, J. L. S. Análise e síntese na abordagem geográfica da pesquisa para o planejamento ambiental. Geografia, Rio Claro, vol. 9, pp.65-75, 1995.

ROSS, J. L. S; FIERZ, M. S. M; VIEIRA, B. C. Técnicas de Geomorfologia. In. VENTURI, Luís Antônio Bittar. (Org.). Geografia: práticas de campo, laboratório e sala de aula. São Paulo: Editora Sarandi, 2011.

SALOMÃO, F. X. T. Controle e Prevenção dos Processos Erosivos. In: GUERRA, A. J. T; SILVA, A. S; BOTELHO, R. G. M. (Org.). Erosão e conservação dos solos: conceitos, temas e aplicações. 6 ed. $^{\underline{a}}$ - Rio de Janeiro: Bertrand Brasil, 2010.

SILVA, E. B.; FERREIRA JÚNIOR, L. G.; ANJOS, A. F.; MIZIARA, F. Análise da distribuição espaço-temporal das pastagens cultivadas no bioma Cerrado entre 1970 e 2006. Revista IDeAS, v. 7, n. 1, p. 174-209, 2013.

SIMONSON, R. W. Modern concepts of soils. Genesis. A symposium outline of a generalized theory of soil genesis. Proc. Soil Sci. Am. 23: 152-156, 1959.

TARIFA, J. R. Mato Grosso: clima: análise e representação cartográfica. (Série recursos naturais e estudos ambientais). Cuiabá, MT: Entrelinhas, 2011.

VALENTE, O. F.; GOMES, M. A. Conservação de nascentes: hidrologia e manejo de bacias hidrográficas de cabeceiras. Viçosa-MG: Aprenda Fácil, 2005.

VASCONCELOS, T. N. N. Interpretação morfopedológica da bacia do rio Tenente Amaral - Jaciara-MT: condição básica para sua caracterização ambiental. 1998, fls.160. Dissertação (Mestrado em Ciências Biológicas) - Universidade Federal de Mato Grosso, Instituto de Ciências Biológicas, Programa de Pós-Graduação em Ciências Biológicas. Cuiabá, 1998.

WWF- BRASIL. Monitoramento das alterações da cobertura vegetal e uso do Solona Bacia do Alto Paraguai - Porção Brasileira - Período de Análise: 2012 a 2014 Iniciativa: Instituto SOS Pantanal, WWF- Brasil. Brasília, 2015. 


\section{NOTAS DE AUTOR}

\section{CONTRIBUIÇÃO DE AUTORIA}

Cleberson Ribeiro de Jesuz - Concepção. Coleta de dados, Análise de dados, Elaboração do manuscrito, revisão e aprovação da versão final do trabalho Ivaniza de Lourdes Lazzarotto Cabral - Concepção e elaboração do manuscrito. Coleta de dados; Participação ativa da discussão dos resultados; Revisão e aprovação da versão final do trabalho.

\section{FINANCIAMENTO}

Apoio da CAPES por meio de bolsa de mestrado, no momento de coleta dos dados. Apoio da FAPEMAT por meio de recursos e diárias advindos do projeto Nutrientes e pesticidas nas águas superficiais das principais bacias do Pantanal setentrional: uma abordagem integrada (Edital nº 009/2009 - PRONEX)" Apoio EMBRAPA Pantanal, por meio do projeto Monitoramento e caracterização quali-quantitativa dos recursos hídricos e sua relação com o uso da terra em bacias experimentais nos diferentes biomas brasileiros", da Rede Agro-Hídro (Chamada 01/2012 - Macroprograma 1).

\section{CONSENTIMENTO DE USO DE IMAGEM}

Não se aplica

\section{APROVAÇÃO DE COMITÊ DE ÉTICA EM PESQUISA}

Não se aplica.

\section{CONFLITO DE INTERESSES}

Não se aplica.

\section{LICENÇA DE USO}

Este artigo está licenciado sob a Licença CreativeCommons CC-BY. Com essa licença você pode compartilhar, adaptar, criar para qualquer fim, desde que atribua a autoria da obra.

\section{HISTÓRICO}

Recebido em: 30-12-2017

Aprovado em: 31-10-2018 